\title{
Belgian Consensus Recommendations to Prevent Vitamin K Deficiency Bleeding in the Term and Preterm Infant
}

\author{
Simon Fiesack ${ }^{1}$, Anne Smits $\left.{ }^{2,3}{ }^{(}\right)$, Maissa Rayyan ${ }^{2,3}$, Karel Allegaert $2,4,5\left({ }^{(}\right.$, Philippe Alliet ${ }^{6}$, Wim Arts ${ }^{7}$, \\ An Bael ${ }^{8}$, Luc Cornette ${ }^{9}$, Ann De Guchtenaere ${ }^{10}$, Nele De Mulder ${ }^{11}$, Isabel George ${ }^{12}$, Elisabeth Henrion ${ }^{13}(\mathbb{D}$, \\ Kirsten Keiren ${ }^{1}$, Nathalie Kreins ${ }^{14}$, Marc Raes ${ }^{6}$, Pierre Philippet ${ }^{15}$, Bart Van Overmeire ${ }^{16}{ }^{\mathbb{D}}$, \\ Myriam Van Winckel ${ }^{17}$, Vinciane Vlieghe ${ }^{18}{ }^{\circ}$, Yvan Vandenplas $8,11, * \mathbb{C}$ and on behalf of the Groups ${ }^{\dagger}$
}

check for

updates

Citation: Fiesack, S.; Smits, A.; Rayyan, M.; Allegaert, K.; Alliet, P.; Arts, W.; Bael, A.; Cornette, L.; De Guchtenaere, A.; De Mulder, N.; et al. Belgian Consensus Recommendations to Prevent Vitamin K Deficiency Bleeding in the Term and Preterm Infant. Nutrients 2021, 13, 4109. https://doi.org/10.3390/nu13114109

Academic Editor: Nadja Haiden

Received: 26 October 2021

Accepted: 9 November 2021

Published: 16 November 2021

Publisher's Note: MDPI stays neutral with regard to jurisdictional claims in published maps and institutional affiliations.

Copyright: (c) 2021 by the authors. Licensee MDPI, Basel, Switzerland. This article is an open access article distributed under the terms and conditions of the Creative Commons Attribution (CC BY) license (https:// creativecommons.org/licenses/by/ $4.0 /)$.
1 Faculty of Medicine, KU Leuven, 3000 Leuven, Belgium; simon.fiesack@student.kuleuven.be (S.F.); kirsten.keiren@hotmail.com (K.K.)

2 Department of Development and Regeneration, KU Leuven, 3000 Leuven, Belgium; anne.smits@uzleuven.be (A.S.); maissa.rayyan@uzleuven.be (M.R.); karel.allegaert@uzleuven.be (K.A.)

3 Neonatal Intensive Care Unit, University Hospitals Leuven, 3000 Leuven, Belgium

4 Department of Pharmacy and Pharmaceutical Sciences, KU Leuven, 3000 Leuven, Belgium

5 Department of Clinical Pharmacy, Erasmus MC, 3011 Rotterdam, The Netherlands

6 Department of Paediatrics, Jessa Hospital, 3500 Hasselt, Belgium; dr.philippe.alliet@gmail.com (P.A.); fa303885@skynet.be (M.R.)

7 Department of Paediatrics, ZOL Genk, 3600 Genk, Belgium; wim.arts@zol.be

8 Department of Pediatrics, ZNA Queen Paola Children's Hospital, Faculty of Medicine UA, 2020 Antwerp, Belgium; anna.bael@zna.be

9 Department of Neonatology, AZ Sint-Jan, 8000 Brugge, Belgium; luc.cornette@azsintjan.be

10 Department of Paediatrics, Ghent University, 9000 Ghent, Belgium; dr.deguchtenaere@gmail.com

11 Vrije Universiteit Brussel (VUB), UZ Bussel, KidZ Health Castle, 1090 Brussels, Belgium; nele.demulder@uzbrussel.be

12 Neonatologie, AZ Groeninge, 8510 Kortrijk, Belgium; dr.isabelgeorge@gmail.com

13 Department of Neonatal Intensive Care, CHR Sambre et Meuse, 5000 Namur, Belgium; elisabeth.henrion@chrsm.be

14 Neonatal Intensive Care Unit, CHC MontLégia, 4000 Liège, Belgium; Nathalie.kreins@chc.be

15 Pediatric Department, CHC MontLégia, 4000 Liège, Belgium; pierre.philippet@chc.be

16 Kind en Gezin-Opgroeien, Vlaamse Overheid, 1000 Brussels, Belgium; bart.vanovermeire@opgroeien.be

17 Department of Paediatrics, Ghent University Hospital, 9000 Ghent, Belgium; Myriam.VanWinckel@uzgent.be

18 Neonatal Intensive Care Unit, Queen Fabiola Children's University Hospital, Université Libre de Bruxelles, 1020 Bruxelles, Belgium; Vinciane.vlieghe@huderf.be

* Correspondence: yvan.vandenplas@uzbrussel.be; Tel.: +32-475748794

+ Groups are listed in acknowledgments.

Abstract: Neonatal vitamin K prophylaxis is essential to prevent vitamin $\mathrm{K}$ deficiency bleeding (VKDB) with a clear benefit compared to placebo. Various routes (intramuscular (IM), oral, intravenous (IV)) and dosing regimens were explored. A literature review was conducted to compare vitamin K regimens on VKDB incidence. Simultaneously, information on practices was collected from Belgian pediatric and neonatal departments. Based on the review and these practices, a consensus was developed and voted on by all co-authors and heads of pediatric departments. Today, practices vary. In line with literature, the advised prophylactic regimen is 1 or $2 \mathrm{mg}$ IM vitamin $\mathrm{K}$ once at birth. In the case of parental refusal, healthcare providers should inform parents of the slightly inferior alternative ( $2 \mathrm{mg}$ oral vitamin $\mathrm{K}$ at birth, followed by 1 or $2 \mathrm{mg}$ oral weekly for 3 months when breastfed). We recommend $1 \mathrm{mg}$ IM in preterm $<32$ weeks, and the same alternative in the case of parental refusal. When IM is perceived impossible in preterm $<32$ weeks, $0.5 \mathrm{mg}$ IV once is recommended, with a single additional IM $1 \mathrm{mg}$ dose when IV lipids are discontinued. This recommendation is a step towards harmonizing vitamin $\mathrm{K}$ prophylaxis in all newborns.

Keywords: vitamin K; vitamin K deficiency bleeding; term; preterm; prophylaxis 


\section{Introduction}

Vitamin K (vit K) refers to a group of fat-soluble vitamins that are important in blood clotting, bone metabolism and regulating blood calcium levels. Neonates are born with very low vit $\mathrm{K} 1$ stores and vit $\mathrm{K}$ is barely detectable in cord plasma. Consequently, vit $\mathrm{K}$ prophylaxis is essential for all neonates [1]. Vit $\mathrm{K}$ does not easily cross the placenta, so that prenatal maternal vit $K$ supplementation does not prevent vit $K$ deficiency bleeding (VKDB). Townsend coined the term 'hemorrhagic disease of the newborn' in 1894 but it was not until the discovery of vit K ('Koagulation vitamin') by Dam and others in the 1930s that the pathophysiology was understood, allowing treatment and prophylaxis [2]. Vit $\mathrm{K}$ deficiency leads to a reduction in the activity of the Vit K-dependent coagulation factors II, VII, IX, X, and of the anticoagulant protein C and protein S. Proteins Induced by Vitamin K Absence (PIVKAs) have been used as surrogate and sensitive markers of vit $\mathrm{K}$ deficiency [3]. PIKVA-II is an immature form of prothrombin (absence of post-translational carboxylation), synthesized in the liver. In the absence of vitamin $\mathrm{K}$ or when its action is antagonized (warfarin), PIVKA-II is released into the blood.

Without prophylaxis, neonates are more prone to develop VKDB. VKDB is defined as 'spontaneous bruising, bleeding or intracranial hemorrhage associated with prolonged clotting times but not due to an inherited coagulopathy or disseminated intravascular coagulation in neonates under 6 months of age' [4]. VKDB is divided into three subcategories according to the age at onset: early VKDB occurring within 0 to $24 \mathrm{~h}$ after birth, classical VKDB between 1 and 7 days after birth and late VKDB after the first week of life [5]. Early VKDB is often located in the head (intracranial, cephalohematoma), intrathoracic, intra-abdominal or gastrointestinal tract [5]. Classic VKDB is mostly located in the gastrointestinal tract, umbilicus, skin, adrenal gland, nose or after circumcision. And late VKDB is often intracranial, skin, gastrointestinal. VKDB can be fatal or cause serious morbidity. In $50 \%$ of the late VKDBs, neonates present with intracranial hemorrhage [5]. Late vit K deficiency usually occurs in exclusively breastfed infants and or infants that have malabsorption disorders or hepatobiliary dysfunction, resulting in cholestasis and an impaired secretion of bile salts leading to malabsorption of vit $K[5,6]$. In the absence of prophylaxis, a VKDB incidence of 5 to 7 per 100,000 live births was reported in Europe [7].

A publication in the Lancet in 1944 initiated the worldwide practice of prophylactic administration of intramuscular (IM) vit $\mathrm{K}$ to neonates [8]. Preterm infants are potentially at greater risk for VKDB than term infants because of delayed enteral feeding and a subsequent delay in the colonization of their gastrointestinal tract with vit $\mathrm{K}$ producing microbiota, as well as immature hepatic and hemostatic function [9]. Frequent and long lasting antibiotic treatments may further affect microbiota growth [10]. However, the impact of the change in microbiota related to antibiotics regarding the risk of VKDB is not clear. The IM route became less obvious once Golding et al. reported in 1992 on the association between IM vit K prophylaxis and different types of childhood cancer [11]. However, despite multiple attempts to confirm this finding, the claimed increased risk in childhood cancer was never replicated [12-14]. Nevertheless, alternative routes of administration were investigated. The incidence of early and classical VKDB is also greatly reduced by administering vit $\mathrm{K}$ by either an oral or intravenous (IV) route $[15,16]$. As these alternative routes became part of our practices, parental refusal for IM prophylaxis became a major issue [17]. The pharmacokinetics of intravenous (IV) vit $K$ are not very well known, but IV administration does not seem to bring the same efficiency as the IM route for the prevention of the late form of VKDB, especially if the injection is not repeated [18]. Moreover, anaphylactic allergic reaction to the IV injection of vit $K$ has been described [19]. As a consequence, there is still a lot of debate and lack of consensus about the optimal regimen (dose, route) of vit $\mathrm{K}$ prophylaxis [20]. A clear, evidence-based guideline on optimal vit $\mathrm{K}$ prophylaxis is needed to provide the best medical care to all neonates. In this literature review, a comparison will be made between different regimens for term and preterm neonates, mainly focusing on prophylactic regimens to prevent late VKDB in breastfed neonates. Simultaneously, information on practices was collected from Belgian 
pediatric and neonatal departments. Based on the literature review and these practices, a consensus was developed and submitted for voting by the co-authors and the heads of the pediatric departments to reach a nationwide guideline in Belgium.

\section{Materials and Methods}

The primary research question was: "What is the optimal dose and mode of administration for vit K prophylaxis in the preterm and term neonate?" A structured literature review was preformed to explore the best evidence-based regimen of vit K prophylaxis. Based on gestational age (GA), 3 groups were defined: very preterm infants with a $\mathrm{GA}<32$ weeks, moderate to late preterm neonates with GA 32 to 37 weeks and term neonates with $\mathrm{GA} \geq 37$ weeks. The intervention was defined as the prophylactic regimen (dose and route of administration) of vit $\mathrm{K}$. The different regimens considered were: oral administration once at birth, oral administration $1 \mathrm{x} /$ day, oral administration $1 \mathrm{x} /$ week, oral administration multiple times in the first days/weeks of life, IM administration once at birth, IV administration once at birth, in different doses for the different routes of administration.

Early, classic, and late VKDB were considered as primary outcomes. Secondary outcomes were serum vit $\mathrm{K}$ level, PIVKA-II and prothrombin time (PT). The normal range in adults of serum vit $\mathrm{K}$ is $0.8-5.4 \mathrm{ng} / \mathrm{mL}$ [21]. A PIVKA-II level of $0.1 \mathrm{AU} / \mathrm{mL}$ or higher is considered as a cut-off for subclinical vit K deficiency in neonates. Since healthy adults do not develop VKDB, it is safe to assume that neonates with a PT equal to the adult range are less prone to develop VKDB. The range of PT in adults is 10.5-12.5 s [22].

The literature search was performed in February 2021 in the PubMed database using the mesh terms: ("Infant, Newborn"[Mesh] OR "Infant, Premature"[Mesh] OR "Infant, Extremely Premature"[Mesh]) OR ("Term Birth"[Mesh] OR "Premature Birth"[Mesh]) OR ("Infant, Low Birth Weight"[Mesh] OR "Infant, Very Low Birth Weight"[Mesh] OR "Infant, Extremely Low Birth Weight"[Mesh]) AND ("Vitamin K"[Mesh]). The articles were screened based on their title. Only articles about vit K prophylaxis in neonates were included for further screening of abstract and full text. In this final screening only clinical (investigational) trials and registry (observational) studies were included. Articles comparing at least 2 vit $\mathrm{K}$ regimens (oral, IM or IV) with well-defined dosages were included. Exclusion criteria were: other study types, other applications of vit K, no primary or secondary outcomes compatible with review outcomes and studies with a focus on professional or parental attitudes.

Alongside the structured review of the literature described above, a questionnaire on the current practice on vit $\mathrm{K}$ prophylaxis in Belgium was sent to all pediatric departments in Flanders and to all Belgian Neonatal Intensive Care Units (NICU). The responses are presented and discussed. All pediatric departments, NICUs and co-authors were offered to participate in a voting regarding the proposed administration of vit $K$, resulting in a broadly supported Belgian consensus recommendation. Statements for voting were scored numerically between 0 (strongly disagree) and 10 (strongly agree), with a predefined cut-off of 7 reflecting agreement $(\geq 7)$ versus disagreement $(<7)$. The Ethics Committee of the University Hospitals Leuven (Belgium) approved the questionnaire protocol (study MP017253).

\section{Results}

\subsection{Literature Review}

A PRISMA flow chart was used to show the results of the literature search (Figure 1).

The search delivered 1034 articles. After screening, 682 articles were retained. In the final review, 26 articles were included. Clinical data extracted from the included studies were vit $\mathrm{K}$ prophylaxis regimen with dose (in $\mathrm{mg}$ ), GA of the neonates (in weeks), number of neonates included, incidence of VKDB, predefined outcomes (serum vit $\mathrm{K}$ at either time, PIVKA-II levels at either time, PT time at either time and/or incidence of VKDB), and number of affected neonates per outcome. An outcome was considered statistically significant when the $p$ value was $<0.05$. 
Systematic search

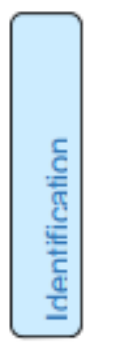

Records identified through

database searching

$(n=1034)$
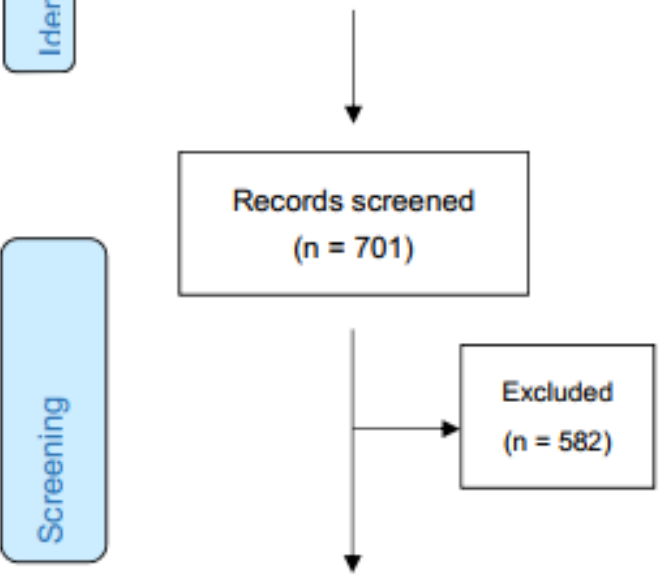
for eligibility

$(n=117)$
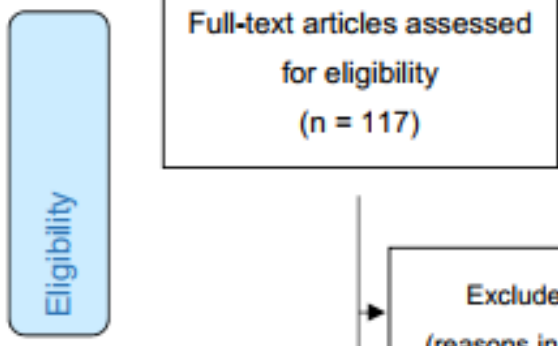

Excluded

(reasons in text)

$(n=91)$

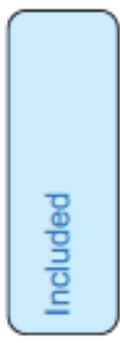

$$
\begin{aligned}
& \text { Studies included in } \\
& \text { qualitative synthesis } \\
& \qquad(n=26)
\end{aligned}
$$

Figure 1. Flow chart literature search.

Articles reporting at least two different prophylactic regimens of vit $\mathrm{K}$ in neonates were retained. Based upon the research question, 26 articles were retained in the final literature review, 11 registry studies and 15 clinical trials. An overview of these articles is provided in Table 1. 
Table 1. Summary of included clinical trials in the literature review.

\begin{tabular}{|c|c|c|c|}
\hline References & Vitamin K Prophylaxis Regimens (mg) & GA (Weeks) Birthweight & $\mathbf{N}^{\circ}$ Study Subjectis \\
\hline Costakos 2003 [23] & IM or IV not specified (1 vs. 0.5 ) & $<32$ & 27 \\
\hline Clarke 2006 [24] & $\begin{array}{l}\text { IM at birth vs. IM at birth vs. IV at birth } \\
\text { (0.5 vs. } 0.2 \text { vs. } 0.2)\end{array}$ & $<32$ & 90 \\
\hline Jørgensen 1991 [25] & $1 \mathrm{mg}$ PO at birth vs. $1 \mathrm{mg} \mathrm{IM}$ at birth & $\geq 35$ & 300 \\
\hline O'Connor 1986 [16] & none vs. $2 \mathrm{mg}$ PO at birth vs. $1 \mathrm{mg} \mathrm{IM}$ at birth & $\geq 37$ & 60 \\
\hline Hathaway 1991 [26] & $\begin{array}{l}2 \mathrm{mg} \text { PO at birth vs. } 5 \mathrm{mg} \text { PO at birth vs. } 1 \mathrm{mg} \\
\text { PO at birth vs. none }\end{array}$ & $\geq 37$ & 36 \\
\hline Cornelissen 1992 [27] & $1 \mathrm{mg}$ PO at birth vs. $1 \mathrm{mg}$ IM at birth & $\geq 37$ & 331 \\
\hline Hogenbirk 1993 [22] & $\begin{array}{l}\text { Formula vs. none vs. } 1 \mathrm{mg} \text { PO at birth vs. } 1 \mathrm{mg} \\
\text { IM at birth }\end{array}$ & $\geq 37$ & 80 \\
\hline Cornelissen 1993 [28] & $\begin{array}{c}1 \mathrm{mg} \text { PO at birth vs. } 1 \mathrm{mg} \text { IM at birth vs. } 1 \mathrm{mg} \\
\text { PO } 1 \times / \text { week vs. } 0.025 \mathrm{mg} \text { PO } 1 \times / \text { day }\end{array}$ & $\geq 37$ & 447 \\
\hline Gupta 1994 [29] & $1 \mathrm{mg} \mathrm{IM}$ at birth vs. $2 \mathrm{mg} \mathrm{PO}$ at birth & $\geq 37$ & 176 \\
\hline Greer 1998 [30] & $1 \mathrm{mg}$ IM at birth vs. $3 \times 2 \mathrm{mg}$ PO & $\geq 37$ & 134 \\
\hline Pereira 2003 [31] & $2 \mathrm{mg} P O$ at birth vs. $1 \mathrm{mg}$ IV at birth & $\geq 37$ & 44 \\
\hline Sann 1985 [32] & none vs. 2 or $5 \mathrm{mg}$ PO or IM at birth not specified & BW (mean) $1800 \mathrm{~g}$ & 26 \\
\hline McNinch 1985 [33] & $\begin{array}{l}1 \mathrm{mg} \text { IM at birth vs. } 1 \mathrm{mg} \text { PO at birth vs. } 1 \mathrm{mg} \\
\text { PO with first feed }\end{array}$ & $\mathrm{BW}>2000 \mathrm{~g}$ & 107 \\
\hline Schubiger 1993 [34] & $1.5 \mathrm{IM}$ at birth vs. $3 \mathrm{mg} \mathrm{PO}$ at birth & $\mathrm{BW}>2000 \mathrm{~g}$ & 25 \\
\hline Shoshkes 1959 [35] & $1 \mathrm{mg}$ IM at birth vs. $2 \mathrm{mg}$ PO at birth vs. none & $?$ & 91 \\
\hline
\end{tabular}

Legend: GA: Gestational Age; IM: intramuscular; IV: intravenous; PO: per os (oral); BW: birthweight; $\mathrm{N}^{\circ}$ : number; ?: not known.

Twenty-three of the articles cover healthy, full-term breastfed neonates. Three articles report on preterm neonates and two articles on neonates with biliary atresia. All but four articles had intramuscular (IM) administration once at birth as the reference regimen against other regimens. Overall, 675 articles were excluded (Figure 1). The main exclusion reasons were other study type (e.g., professional opinions and commentary articles on IM vit $\mathrm{K}$ prophylaxis), articles with no full text or other language (not Dutch or English), different methods of vit K prophylaxis (e.g., transdermal administration or administration of vit $\mathrm{K}$ prenatally to the mothers) and other aspects of prophylactic vitamin K (e.g., investigating adverse effects of vit $\mathrm{K}$ use). Finally, articles on the therapeutic use of vit $\mathrm{K}$ in neonates or young children with bleedings, rather than the prophylactic use, were excluded as well.

In Table 2, a summary of the 15 included clinical trials is presented. The population evaluated in the papers is: 10 articles on GA $\geq 37$ weeks, one article on GA $\geq 32-<37$ weeks, three articles with GA $<32$ weeks or low birth weight (mean birth weight of $1800 \mathrm{~g}$ ) and one in which GA was not specified. IM administration once at birth is used in 13 articles (with doses varying from 0.2 to $5 \mathrm{mg}$ ), IV administration once at birth in three articles, oral administration once at birth in 12 articles, oral administration multiple times in the first days/weeks of life in two articles and no vit K prophylaxis as control in four papers. In two articles there was a comparison with formula-fed neonates.

In Table 3, a summary of the 11 included registry studies is presented. In all articles the population consisted of neonates, not further specified, except for two papers on neonates with (not yet diagnosed) biliary atresia. The primary outcome of these publications is the incidence of VKDB in neonates. IM administration once at birth is used in nine articles, IV administration once at birth is not used, oral administration once at birth in two articles, oral administration multiple times in the first days/weeks of life in seven papers and no vit $\mathrm{K}$ prophylaxis as control in four. In one article there was a comparison between breastand formula-fed neonates. In three articles the dose administered was not specified. 
Table 2. Summary of included registry studies in the literature review.

\begin{tabular}{|c|c|c|c|}
\hline Reference & Vitamin K Prophylaxis & Period & $\mathrm{N}^{\circ}$ of VKDB/Population (\%) \\
\hline von Kries 1992 [36] & none vs. $1 \mathrm{mg}$ IM at birth vs. $2 \mathrm{mg}$ PO at birth & 1988-1989 & $14 / 750,000(0.0019)$ \\
\hline Cornelissen 1997 [37] & $\begin{array}{l}1 \mathrm{mg} \text { PO at birth }+0.025 \mathrm{mg} / \text { day vs. } \\
3 \times 1 \mathrm{mgPO} \text { vs. } 1 \mathrm{mg} \text { IM at birth vs. } 2 \times 2 \mathrm{mg} \text { P0 }\end{array}$ & 1992-1995 & $49 / 2,372,000(0.0021)$ \\
\hline von Kries 1999 [4] & $3 \mathrm{mg}$ PO vs. $3 \times 1 \mathrm{mg}$ PO & 1995-1998 & $23 / 3,200,000(0.007)$ \\
\hline Hansen 2003 [38] & $\begin{array}{l}2 \mathrm{mg} \text { PO at birth }+1 \mathrm{mg} / \text { week vs. } 1 \mathrm{mg} \text { IM at } \\
\text { birth }+1 \mathrm{mg} \text { PO } 1 \times / \text { week }\end{array}$ & $1992-2000$ & $0 / 507,850(0)$ \\
\hline McNinch 2007 [39] & $\begin{array}{c}\text { none vs. } 1 \times \mathrm{PO}, 2 \times \mathrm{PO} \text { or } 3 \times \mathrm{PO} \text { in first days vs. } \\
\mathrm{IM} \text { at birth }\end{array}$ & $\begin{array}{l}1988-1990 \\
1993-1994 \\
2001-2002\end{array}$ & $\begin{array}{l}27 / 1,671,000(0.016) \\
32 / 1,609,785(0.020) \\
7 / 1,456,200(0.005)\end{array}$ \\
\hline Darlow 2011 [40] & none vs. IM at birth (not specified) & 1998-2008 & $17 / 1,288,018\left(^{*}\right)(0.013)$ \\
\hline Busfield 2013 [41] & $\begin{array}{l}\text { none vs. IM at birth vs. PO at birth } \\
\text { (not specified) }\end{array}$ & $2006-2008$ & $11 / 1,700,000(0.007)$ \\
\hline Löwensteyn 2019 [42] & $\begin{array}{c}1 \mathrm{mg} \text { PO at birth }+0.025 / \text { day vs. } 1 \mathrm{mg} \text { PO at } \\
\text { birth }+0.150 \mathrm{mg} / \text { day } \\
\text { Late intracranical VKDB }\end{array}$ & $\begin{array}{l}2008-2011 \\
2011-2015\end{array}$ & $\begin{array}{l}18 / 583,117(0.031) \\
10 / 843,820(0.011)\end{array}$ \\
\hline Zurynski 2020 [43] & $3 \times 2 \mathrm{mg}$ PO vs. $1 \mathrm{mg}$ IM once at birth & 1993-2017 & $58 / 6,904,762\left(^{*}\right)(0.008)$ \\
\hline Witt $2016[44]^{\circ}$ & $\begin{array}{c}1 \mathrm{mg} \text { PO at birth }+0.025 \mathrm{mg} / \text { day vs. } 1 \mathrm{mg} \text { PO at } \\
\text { birth }+0.150 \mathrm{mg} / \text { day vs. } 2 \mathrm{mg} \text { IM at birth } \\
\text { (biliary atresia) }\end{array}$ & & $55 / 90(611)$ \\
\hline van Hasselt 2008 [45] $^{\circ}$ & $\begin{array}{c}1 \mathrm{mg} \text { PO at birth }+0.025 / \text { day vs. } 2 \mathrm{mg} \text { PO at } \\
\text { birth }+1 \mathrm{mg} \text { / week vs. } 2 \mathrm{mg} \text { IM at birth vs. none } \\
\text { in Formula (biliary atresia) }\end{array}$ & & 28/151 (185) \\
\hline
\end{tabular}

Legend: $\mathrm{VKDB}=$ vitamin $\mathrm{K}$ deficiency bleeding, $\mathrm{PO}=$ per os, IM = intramuscular; IV: intravenous; $\left({ }^{*}\right)=$ calculated based upon overall incidence.; ${ }^{\circ}$ : both studies are in infants with biliary atresia; the cholestasis causes malabsorption of lipids and thus also of lipid soluble vitamins.

A detailed representation of the results of the registry studies is presented in Table 2. The incidence of VKDB in neonates receiving vit $\mathrm{K} 1 \mathrm{mg}$ IM once at birth was statistically significantly lower or equal to other regimens. Based on the mean incidence of the different regimens, $1 \mathrm{mg}$ IM once at birth, $1 \mathrm{mg}$ or $2 \mathrm{mg}$ oral administration once at birth followed by $1 \mathrm{mg}$ oral once per week, and formula-fed neonates have a significantly lower incidence compared to other regimens. It is noted that the weekly oral regimen was only reported once, leading to potential bias.

Three articles discussed all predefined secondary outcomes of this review [22,24,30]. Three articles reported short term variables within the first $24 \mathrm{~h}$ of life [31,32,34], 10 articles between day 1 and day 7 of life $[16,22,26-28,30,31,46-48]$ and eight articles after the first week of life $[22,24,26-28,30,32,34]$, correlating with early, classic and late VKDB, respectively.

In term neonates the levels of serum vit $\mathrm{K}$ in the first $24 \mathrm{~h}$ when given $1 \mathrm{mg}$ IV or $1 \mathrm{mg}$ IM once at birth was significantly higher compared to 1 or $2 \mathrm{mg}$ oral once at birth. The serum vit $\mathrm{K}$ level in the first week of life of the term neonate is not different between the $2 \mathrm{mg}$ oral once at birth and the $1 \mathrm{mg}$ IM once at birth regimen. Schubiger et al. reported in 1993 that a significantly higher serum vit K level at day 4 of life was observed when $3 \mathrm{mg}$ oral once at birth was administered compared to $1.5 \mathrm{mg}$ IM once at birth [34].

After the first week of life, a significantly higher serum vit $\mathrm{K}$ level is documented in the groups receiving $1 \mathrm{mg}$ or $1.5 \mathrm{mg} \mathrm{IM}$ once at birth compared to $1 \mathrm{mg}$ or $3 \mathrm{mg}$ oral once at birth $[22,27,28]$. Greer et al. reported a significantly higher serum vit K level when $3 \times 2 \mathrm{mg}$ oral in the first days of life was administered compared to $1 \mathrm{mg} \mathrm{IM}$ once at birth [30] and Cornelissen et al. reported significantly higher serum vit $\mathrm{K}$ levels in the weekly or daily oral regimen compared to either IM or PO once at birth [28]. 
The articles on premature or low birth weight neonates (mean birth weight $1800 \mathrm{~g}$ ) as population, compared different vit $K$ dosages for the same route of administration [24,28,32]. No significantly different serum vit $\mathrm{K}$ level was reported when the same dose was administered, independent of the route of administration. In the first $24 \mathrm{~h}$, the first week and up to the postnatal age of 25 days the reported serum vit $\mathrm{K}$ in all articles were equal to or above the adult range $(0.8-5.4 \mathrm{ng} / \mathrm{mL})$.

Only one article documented significantly different PIVKA-II levels. In this article, the PIVKA-II levels were significantly higher at 12 weeks of life after $1 \mathrm{mg}$ oral or IM once at birth compared to the weekly or daily oral regimen of $25 \mu \mathrm{g}$ in term neonates [28].

PT was not significantly different between the investigated regimens, except for one paper by O'Connor et al. 1986, reporting a significantly higher PT when no vit K prophylaxis was given compared to $2 \mathrm{mg}$ oral or $1 \mathrm{mg}$ IM once at birth [16]. In the other studies, PT values were within or above the adult range in the first days of life [22,24,25,30,35].

\subsection{Current Practices in Belgium}

Tables 3 and 4 summarize the daily practice in the maternity wards in Flanders (response rate 95\% (54/57)) for formula and breastfed term born infants [49]. The ratio IM versus oral administration is close to a fifty-fifty distribution. In 9 out of 13 maternity wards ( $17 \%$ of all participating maternity wards) that adapted the policy regarding vit K prophylaxis after 2015, the change was from oral towards IM prophylaxis. The other adaptations concerned dosage. Table 5 lists the currently used vit K prophylaxis protocols in the Belgian Neonatal Intensive Care Units (NICU).

Table 3. Vitamin K prophylaxis for term breastfed infants in Flanders (Reprinted with permission from ref. [49]. Copyright 2021 Belgian Society of Paediatrics.).

\begin{tabular}{|c|c|c|c|c|}
\hline Route & $\mathbf{N}^{\circ}$ Responses & Regimen & $\mathbf{N}^{\circ} \mathbf{I}$ & s $(\%)$ \\
\hline \multirow{2}{*}{ Intramuscular } & \multirow{2}{*}{$29(54 \%)$} & $1 \mathrm{mg}$ IM immediately after birth & 28 & $(52 \%)$ \\
\hline & & 2 mg IM immediately after birth & 1 & $(2 \%)$ \\
\hline \multirow{6}{*}{ Oral } & \multirow{6}{*}{$25(46 \%)$} & $2 \mathrm{mg}$ oral at birth and maintenance dose $1-2 \mathrm{mg} /$ week & 14 & $(26 \%)$ \\
\hline & & $1 \mathrm{mg}$ oral at birth and maintenance dose $150 \mu \mathrm{g} /$ day & 6 & $(11 \%)$ \\
\hline & & $2 \mathrm{mg}$ oral at birth and maintenance dose $25 \mu \mathrm{g} /$ day & 3 & $(6 \%)$ \\
\hline & & $2 \mathrm{mg}$ oral at birth and maintenance dose $150 \mu \mathrm{g} /$ day & 1 & $(2 \%)$ \\
\hline & & 2 mg oral at birth: no information on maintenance dose & 1 & $(2 \%)$ \\
\hline & & $2 \mathrm{mg}$ oral at birth, $2 \mathrm{mg}$ oral day $4-6$ and $2 \mathrm{mg}$ at $4-6$ weeks & 0 & $(0 \%)$ \\
\hline
\end{tabular}

Table 4. Vitamin K prophylaxis for term formula-fed infants in Flanders (Reprinted with permission from ref. [49]. Copyright 2021 Belgian Society of Paediatrics.).

\begin{tabular}{|c|c|c|c|c|}
\hline Route & $\mathbf{N}^{\circ}$ Responses & Regimen & \multicolumn{2}{|c|}{$\mathbf{N}^{\circ}$ Responses(\%) } \\
\hline \multirow{2}{*}{ Intramuscular } & \multirow{2}{*}{$30(56 \%)$} & $1 \mathrm{mg} \mathrm{IM}$ at birth & 29 & $(54 \%)$ \\
\hline & & $2 \mathrm{mg}$ IM at birth & 1 & $(2 \%)$ \\
\hline \multirow{2}{*}{ Oral } & \multirow{2}{*}{$24(44 \%)$} & $2 \mathrm{mg}$ oral at birth & 23 & $(43 \%)$ \\
\hline & & $1 \mathrm{mg}$ oral at birth & 1 & $(2 \%)$ \\
\hline
\end{tabular}


Table 5. Vitamin K administration immediately at birth in NICUs in Belgium (preterm and sick term).

\begin{tabular}{|c|c|c|c|}
\hline Centre & Preference & Route & Follow-Up \\
\hline \multirow[t]{3}{*}{1} & $<1 \mathrm{~kg}$ & $\begin{array}{c}\text { IV } 1 \mathrm{mg} \\
\text { oral } 10 \mu \mathrm{g}(2 \mathrm{dr})^{\circ}\end{array}$ & $\begin{array}{l}\text { None } \\
\text { ? }\end{array}$ \\
\hline & $1-2 \mathrm{~kg}$ & $\begin{array}{c}\text { IV } 1 \mathrm{mg} \\
\text { oral } 2 \mathrm{mg} \\
\text { oral } 10 \mu \mathrm{g}(2 \mathrm{dr})^{\circ}\end{array}$ & $\begin{array}{c}\text { None } \\
? \\
25 \mu \mathrm{g} / \text { day up to } 3 \text { months if breastfed and no HMF }\end{array}$ \\
\hline & $>2 \mathrm{~kg}$ & $\begin{array}{c}\text { IV } 2 \mathrm{mg} \\
\text { oral } 2 \mathrm{mg} \\
\text { oral } 25 \mu \mathrm{g}(5 \mathrm{dr})^{\circ}\end{array}$ & $\begin{array}{c}\text { None } \\
? \\
25 \mu \mathrm{g} / \text { day up to } 3 \text { months if breastfed and no HMF }\end{array}$ \\
\hline 2 & $<39$ weeks and/or $<3000 \mathrm{~g}$ & IV $2 \mathrm{mg}$ & $\begin{array}{l}\text { If IV lipid }<2 \mathrm{~g} / \mathrm{kg} / \text { day: } 1 \mathrm{mg} \text { vit } \mathrm{K} / \text { day IV } \\
\text { If }>50 \% \text { breastmilk: } 10 \mu \mathrm{g} / \text { day ( } 2 \text { drops) }\end{array}$ \\
\hline \multirow[t]{2}{*}{3} & $<1500 \mathrm{~g}$ & IV $0.5 \mathrm{mg}$ & $0.5 \mathrm{mg}$ IV / day (up to stop infusion) \\
\hline & $>1500 \mathrm{~g}$ & IM $1 \mathrm{mg}$ & \\
\hline \multirow[t]{2}{*}{4} & (partial)(total) PN & & $\begin{array}{c}\text { >36 weeks: IV } 1 \mathrm{mg} / \text { day } \\
<36 \text { weeks: IV } 1 \mathrm{mg} / \text { day up to day } 6 \text {, followed by IV } 1 \mathrm{mg} \\
3 x / \text { week }\end{array}$ \\
\hline & Breastfeeding ( $>50 \%$ intake) & & $\begin{array}{l}\text { In NICU: oral } 2 \mathrm{mg} / \text { week up to } 3 \text { months } \\
\text { Out: oral } 25 \mu \mathrm{g} / \text { day ( } 5 \mathrm{dr})\end{array}$ \\
\hline \multirow[t]{2}{*}{5} & $<34$ weeks & IV $1 \mathrm{mg}$ & oral or IV $1 \mathrm{mg} /$ week during 10 weeks \\
\hline & $\geq 34$ weeks & IV $2 \mathrm{mg}$ & oral or IV $2 \mathrm{mg}$ /week during 10 weeks \\
\hline 6 & Preterm in NICU & IV $1 \mathrm{mg}$ & $\begin{array}{c}\text { If TPN: no vit K } \\
\text { If breastfeeding with HMF/formula: no vit } \mathrm{K} \\
\text { If breastfeeding: } 25 \mu \mathrm{g} / \text { day }(5 \mathrm{dr}) \text { when dismissed }\end{array}$ \\
\hline \multirow[t]{2}{*}{7} & $<36$ wks & IM $0.5 \mathrm{mg}$ & None \\
\hline & & IV $0.5 \mathrm{mg}$ & oral $1 \mathrm{mg} /$ week up to diversification \\
\hline 8 & All ages & IV /IM $1 \mathrm{mg}$ & \\
\hline \multirow[t]{4}{*}{9} & $<35$ weeks and $<1500 \mathrm{~g}$ & IV $0.5 \mathrm{mg}$ & $>$ Day 7 and no IV line: oral $2 \mathrm{mg} /$ week if breastfeeding \\
\hline & $<35$ weeks and $\geq 1500 \mathrm{~g}$ & IV $1 \mathrm{mg}$ & $>$ Day 7 and no IV line: oral $2 \mathrm{mg} /$ week if breastfeeding \\
\hline & $>35$ weeks and NICU & IV $1 \mathrm{mg}$ & >Day 7 and no IV line: oral $2 \mathrm{mg} /$ week if breastfeeding \\
\hline & $>35$ weeks and healthy & PO 2 mg & $>$ Day 7 and no IV line: oral $2 \mathrm{mg} /$ week if breastfeeding \\
\hline 10 & $>35$ weeks and NICU & IV /IM 2 mg & None \\
\hline 11 & $\begin{array}{l}\geq 36 \text { weeks } \\
<36 \text { weeks }\end{array}$ & $\begin{array}{l}\text { IM } 1 \mathrm{mg} \\
\text { IV } 1 \mathrm{mg} / \mathrm{kg}\end{array}$ & $\begin{array}{c}\text { None } \\
\text { Day 1-14: IV } 0.1 \mathrm{mg} / \mathrm{kg} \text { (minimum } 0.1 \mathrm{mg}) \text {, or oral } 1 \mathrm{mg}(<2 \mathrm{~kg}) \\
\text { to } 2 \mathrm{mg}(>2 \mathrm{~kg}) \text {. Day } 14-3 \text { months if breastfeeding: same regimen } \\
1 \mathrm{x} / \text { week }\end{array}$ \\
\hline
\end{tabular}

Legend: ${ }^{\circ}$ : if $>50 \%$ mother's milk and no human milk fortifier or vitalipid; NICU: neonatal intensive care unit, HMF: human milk fortifier; TPN: total parenteral nutrition.

\subsection{The Consensus}

Based on the literature review, the following statements were sent to all co-authors and to the heads of the departments of pediatrics in Flanders. The response rate was $56 / 74(75.7 \%)$ (some of the co-authors are also heads of departments). All statements reached consensus (84-100\%) (Table 6). The major reason for disagreement was restraint from IM injection in preterms, despite the minimal volume $(0.1 \mathrm{~mL}$ for $1 \mathrm{mg})$. 
Table 6. Voting results (scores $0-10$ ) on the statements on vitamin K prophylaxis.

\begin{tabular}{|c|c|c|}
\hline Statements & Mean & $\begin{array}{l}\text { Disagree (N) } \\
\quad \text { (Score) }\end{array}$ \\
\hline $\begin{array}{l}\text { Statement } 1 . \text { For term born infants, we recommend the administration of } 1 \mathrm{mg} \text { IM vit } \mathrm{K} \\
\text { once at birth to all term neonates. }\end{array}$ & 9.02 & $5 / 56(2,4,5,5)$ \\
\hline $\begin{array}{l}\text { Statement } 2 \mathrm{~A} \text {. In case of parental refusal of the IM administration, the health care } \\
\text { provider should inform the parents about a slightly inferior alternative option: } 2 \mathrm{mg} \\
\text { oral vit } \mathrm{K} \text { at birth followed by the administration of } 1 \text { or } 2 \mathrm{mg} \text { oral vit } \mathrm{K} 1 \mathrm{x} \text { per week } \\
\text { during } 3 \text { months in breastfed infants, with specific attention to compliance. }\end{array}$ & 9.07 & $3 / 56(2,4,6)$ \\
\hline $\begin{array}{l}\text { Statement 2B. No further supplementation is needed after birth in formula-fed infants, } \\
\text { even in mixed breast- and formula-feeding (if formula feeding }>50 \% \text { of the intake). }\end{array}$ & 8.75 & $5 / 56(1,4,5,6,6)$ \\
\hline $\begin{array}{l}\text { Statement 3A. In preterm neonates (also }<32 \text { weeks gestation), we recommend the same } \\
\text { approach as in term neonates. }\end{array}$ & 8.41 & $4 / 56(1,1,3,4)$ \\
\hline $\begin{array}{l}\text { Statement } 3 \mathrm{~B} \text {. In case IM administration is not possible, } 0.5 \mathrm{mg} \text { IV single administration } \\
\text { at birth is recommended, followed by } 1 \mathrm{mg} \text { IM administration when IV lipids } \\
\text { are discontinued. }\end{array}$ & 8.25 & $9 / 56(1,1,4,5,5,6,6,6,6)$ \\
\hline $\begin{array}{l}\text { Statement } 4 \text {. Infants with cholestasis or another disease associated with } \\
\text { fat-malabsorption need vit } \mathrm{K} \text { (and other fat-soluble vitamin) supplementation regardless } \\
\text { of the mode of feeding in order to prevent vitamin } \mathrm{K} \text { deficient coagulation disorder. }\end{array}$ & 9.39 & 0 \\
\hline
\end{tabular}

Legend: N: number of votes.

\section{Discussion}

This review of the literature allows to conclude that considering advantages and disadvantages of each regimen, $1 \mathrm{mg}$ IM vit $\mathrm{K}$ once at birth to all term neonates can be advised as a first option. Because most infant formula is fortified with approximately $50 \mu \mathrm{g} / \mathrm{L}$ of vit $\mathrm{K}$ (range from $39 \mu \mathrm{g} / \mathrm{L}$ in starter formula to $85 \mu \mathrm{g} / \mathrm{L}$ in human milk fortifier, compared to $3 \mu \mathrm{g} / \mathrm{L}$ in human milk), VKDB is now mostly confined to breastfed neonates [20].

The prevention of VKDB was introduced in the 1940s with the administration of vit $\mathrm{K}$ [8]. Over the last decades, an international debate about the best prophylactic regimen was ongoing and still remains without consensus [50]. The pros and cons of oral versus IM prophylaxis, as well as the most optimal dose, is still a topic of discussion [20]. A single dose of vit K orally at birth prevents early and classical VKDB; however, this regimen fails to prevent late VKDB, even in very high dosages [51]. A single dose of vit K IM at birth (dose not mentioned) is reported to be the most effective in preventing classical as well as late VKDB, reducing the incidence to 0.2 per 100,000 live births [7]. Despite a long experience with prophylactic vit $\mathrm{K}$, failures of adherence to prophylactic oral administration regimens still occur. Parents may simply forget to administer the oral vit $\mathrm{K}$. These failures also occur in neonates who were later diagnosed with a cholestatic liver disease or other diseases related to malabsorption such as cystic fibrosis $[52,53]$. Due to the absence of intestinal bile in cholestatic neonates, the absorption of vit $\mathrm{K}$ and other fat-soluble vitamins is greatly reduced.

The overall incidence of VKDB decreased over time since an increasing number of countries and maternities implemented more effective regimens of vit $\mathrm{K}$ prophylaxis. Since 1961 the American Academy of Pediatrics (AAP) has recommended a single dose of 0.5 or $1 \mathrm{mg} \mathrm{IM}$ vit $\mathrm{K}$ once at birth or 1 or $2 \mathrm{mg}$ oral vit $\mathrm{K} 1 \mathrm{x}$ at birth to the neonate to prevent VKDB [54]. The 2003 recommendation by the AAP is $1 \mathrm{mg}$ IM vit $\mathrm{K}$ once at birth [50,55]. The Canadian Paediatric Society recommended a similar prophylaxis regimen, but suggested as an alternative a regimen of $2 \mathrm{mg}$ oral within $6 \mathrm{~h}$ after birth, repeating it at 2 to 4 weeks and at 6 to 8 weeks of age [56]. In 2018, an oral regimen was added to the Canadian recommendations: $2 \mathrm{mg}$ oral vit $\mathrm{K}$ at birth following a weekly dose of $1 \mathrm{mg}$ oral vit $\mathrm{K}$ for 3 months [57]. The European Society for Paediatric Gastroenterology Hepatology and Nutrition (ESPGHAN) suggests the same regimens as the Canadian recommendation [58]. 
Wariyar et al. reviewed the incidence of late VKDB in various population studies, excluding cases where bleeding occurred because prophylactic vit $\mathrm{K}$ was not given, and could confirm the need for vit K prophylactic administration to prevent late VKDB [59]. It is strongly suggested in this paper that IM administration is more effective (Table 7) [59].

Table 7. Number (/10,000 cases) of late vitamin K deficiency bleeding in different populations according to prophylactic regimen (Adapted from ref. [59]).

\begin{tabular}{|c|c|c|}
\hline Prophylaxis & Country (Period) & $\mathrm{N}^{\circ}$ of Late $\mathrm{VKDB} / \mathbf{1 0 , 0 0 0}$ \\
\hline \multirow[t]{4}{*}{ No } & Japan 1978-1980 & 860 \\
\hline & Japan 1981-1985 & 718 \\
\hline & UK 1988-1989 & 454 \\
\hline & Germany 1988 & 721 \\
\hline \multirow[t]{4}{*}{ 1-2 mg oral once at birth } & Switzerland 1986-1987 & 642 \\
\hline & UK 1988-1989 & 1420 \\
\hline & Sweden 1987-1989 & 511 \\
\hline & Denmark 1990-1992 & 446 \\
\hline \multirow[t]{2}{*}{$1 \mathrm{mg}$ oral at birth and at 1 and $3-5$ weeks } & Australia 1993-1998 & 197 \\
\hline & Germany 1993-1994 & 183 \\
\hline $2 \mathrm{mg}$ oral at birth and at 1 and 4 days & Switzerland 1995 & 121 \\
\hline $1 \mathrm{mg}$ oral at birth and at 2,4 and 6 weeks & North of England 1993-1998 & 103 \\
\hline $1 \mathrm{mg}$ oral at birth and $25 \mu \mathrm{g} /$ day up to 3 months & Netherlands & 68 \\
\hline $2 \mathrm{mg}$ oral at birth and $1 \mathrm{mg}$ weekly for 3 months & Denmark 1993-1998 & 0 \\
\hline \multirow[t]{2}{*}{$1 \mathrm{mg}$ intramuscular at birth } & UK 1988-1989 & 0 \\
\hline & Australia 1993-98 & 0.01 \\
\hline
\end{tabular}

Legend: Number $\left(\mathrm{N}^{\circ}\right)$ of late VKDB: number of late vitamin $\mathrm{K}$ deficiency bleedings.

In 2016, Witt et al. compared the efficacy of the Dutch regimen of oral prophylaxis ( $1 \mathrm{mg}$ of vit K orally at birth followed by $150 \mu \mathrm{g}$ daily from week 2 to week 13) with the Danish regimen (single IM dose of $1 \mathrm{mg}$ at birth) in breastfed infants [44]. It has been reported that an error occurred in the original paper, as the IM dose was $1 \mathrm{mg}$, not $2 \mathrm{mg}$ [44]. Results evidenced that oral strategy failed to prevent VKDB in infants with undiagnosed cholestasis, such as biliary atresia [44]. Prevention was effective in the case of IM administration. However, even after administering $1 \mathrm{mg}$ IM once at birth or $1 \mathrm{mg}$ oral weekly, not all cases of late VKDB were prevented [41,60,61]. Table 8 provides information of recommendations for vit K prophylaxis in term infants for different countries. Different forms of vit K exist: phylloquinone and menaquinones [60]. Phylloquinone, which is the major dietary source, is concentrated in leafy plants and is the vitamin $\mathrm{K}$ form best characterized in terms of food composition and dietary intake. In contrast, menaquinones are the product of bacterial production or conversion from dietary phylloquinone. Most countries recommend phylloquinone for vit $\mathrm{K}$ prophylaxis, except Japan, which uses menaquinone-4 [60].

The questionnaire to retrieve information regarding the daily practice for vit administration in term born infants in the maternity wards in Flanders had a remarkable response rate of $95 \%(54 / 57)$ [49]. The outcome of this questionnaire illustrates very well the debate about the best way to administer vit K prophylaxis. While there is $100 \%$ conviction that vit $\mathrm{K}$ administration immediately after birth is mandatory, there is no agreement about the best way to administer the vit $\mathrm{K}$, since $54 \%$ administer vit $\mathrm{K}$ IM and $46 \%$ oral [49]. When the same colleagues were contacted to vote on the new consensus statements based on this 
review of the literature, we succeeded in convincing most of the respondents to switch to

IM administration since only $5 \%$ continued to prefer the oral administration of vit $\mathrm{K}$.

Table 8. Vitamin K recommendation to prevent VKDB in term infants.

\begin{tabular}{|c|c|c|c|}
\hline Country & Preference & Route at Birth & Follow-Up \\
\hline Germany & IM/oral & $\begin{array}{l}\text { IM } 1 \mathrm{mg} \\
\text { oral } 2 \mathrm{mg}\end{array}$ & $\begin{array}{c}\text { None } \\
2 \mathrm{mg} \text { week } 1 \text { and week } 4\end{array}$ \\
\hline Austria & Oral & oral $2 \mathrm{mg}$ & $2 \mathrm{mg}$ day $4-6$ and $2 \mathrm{mg}$ week $4-6$ \\
\hline UK & IM & $\begin{array}{l}\text { IM } 1 \mathrm{mg} \\
\text { oral } 2 \mathrm{mg}\end{array}$ & $\begin{array}{l}\text { None } \\
2 \mathrm{mg} \text { week } 1 \text { and } 2 \mathrm{mg} \text { week } 4 \text { (only BF) }\end{array}$ \\
\hline Ireland & IM & $\begin{array}{l}\text { IM } 0.8-1.0 \mathrm{mg}^{\circ} \\
\quad \text { oral } 2 \mathrm{mg}\end{array}$ & $\begin{array}{c}\text { None } \\
2 \mathrm{mg} \text { day } 4-7 \text { and } 2 \mathrm{mg} \text { week } 4 \text { (only BF) }\end{array}$ \\
\hline Danmark & $\mathrm{IM}$ & IM $2 \mathrm{mg}$ & None \\
\hline Norway & $\mathrm{IM}$ & IM $0.5-1 \mathrm{mg}$ & None \\
\hline Finland & $\mathrm{IM}$ & $\begin{array}{l}\text { IM } 1 \mathrm{mg} \\
\text { oral } 2 \mathrm{mg}\end{array}$ & $\begin{array}{c}\text { None } \\
2 \mathrm{mg} \text { week } 1 \text { and } 2 \mathrm{mg} \text { week } 4\end{array}$ \\
\hline France & oral & oral $2 \mathrm{mg}$ & $2 \mathrm{mg}$ day $3-7$ and $2 \mathrm{mg}$ week 4 \\
\hline Greece & IM & IM $1 \mathrm{mg}$ & None \\
\hline Italy & IM & IM 2 mg & None \\
\hline Latvia & $\mathrm{IM} /$ oral & $\begin{array}{l}\text { IM } 1 \mathrm{mg} \\
\text { oral } 2 \mathrm{mg}\end{array}$ & $\begin{array}{l}\text { None } \\
2 \text { mg week } 1 \text { and } 2 \text { mg week } 3-4\end{array}$ \\
\hline Lithuania & IM & $\begin{array}{l}\text { IM } 1 \mathrm{mg}(>1500 \mathrm{~g} \mathrm{BW}) \\
\text { oral } 2 \mathrm{mg}\end{array}$ & $\begin{array}{c}\text { None } \\
2 \mathrm{mg} \text { day } 3-7 \text { and } 2 \mathrm{mg} \text { week } 6\end{array}$ \\
\hline Czech Republic & IM/oral & $\begin{array}{l}\text { IM } 1 \mathrm{mg} \\
\text { oral } 2 \mathrm{mg}\end{array}$ & $\begin{array}{c}\text { None } \\
2 \mathrm{mg} / \text { week during } 10-12 \text { weeks }\end{array}$ \\
\hline Slovenia & IM & IM $1 \mathrm{mg}$ & None \\
\hline Switzerland & oral & oral $2 \mathrm{mg}$ & $2 \mathrm{mg}$ day 4 and $2 \mathrm{mg}$ week 4 \\
\hline USA & $\mathrm{IM}$ & $\begin{array}{c}\text { IM } 0.5-1 \mathrm{mg} \\
\text { oral 2-4 mg after 1st feeding }\end{array}$ & $\begin{array}{c}\text { None } \\
2 \mathrm{mg} \text { week } 2-4 \text { and } 2 \mathrm{mg} \text { week } 6-8 \\
2 \mathrm{mg} \text { week } 1 \text { and } 2 \mathrm{mg} / \text { week during BF } \\
2 \mathrm{mg} \text { week } 1 \text { and } 25 \mu \mathrm{g} / \text { day during } 13 \text { weeks }\end{array}$ \\
\hline Canada & $\mathrm{IM}$ & IM 1 mg ( $\geq 1500$ BW) & None \\
\hline $\begin{array}{c}\text { Australia } \\
\text { New Zealand }\end{array}$ & IM & $\begin{array}{l}\text { IM } 1 \mathrm{mg}(\geq 1500 \mathrm{~g}) \\
\text { oral } 2 \mathrm{mg} \\
\text { IV0.3 mg/kg } \\
(0.2-0.5 \mathrm{mg} / \mathrm{kg}) *\end{array}$ & $\begin{array}{c}\text { None } \\
2 \text { mg day 3-5 and } 2 \text { mg week } 4-6 \text { (day 22-28) } \\
\text { Repeat if vomits within } 1 \text { h or diarrhea } \\
\text { within } 1 \text { day after administration } \\
\text { Can be repeated weekly }\end{array}$ \\
\hline WHO & IM & IM $1 \mathrm{mg}$ & None \\
\hline ESPGHAN & $\mathrm{IM}$ & $\begin{array}{l}\text { IM } 1 \mathrm{mg} \\
\text { oral } 2 \mathrm{mg}\end{array}$ & $\begin{array}{c}\text { None } \\
2 \mathrm{mg} \text { day } 4-6 \text { and } 2 \mathrm{mg} \text { week } 4-6 \\
1 \mathrm{mg} / \text { week for } 3 \text { months }\end{array}$ \\
\hline
\end{tabular}

Legend: IM: intramuscular; BF: breastfeeding; ${ }^{\circ}$ : depending on weight; ${ }^{*}$ : in sick infants if unable to give IM or oral; WHO: World Health Organization; ESPGHAN: European Society for Paediatric Gastroenterology Hepatology and Nutrition.

Compliance is not an issue when parenteral prophylaxis is applied, except if the administration is unintentionally omitted. Compliance is a more relevant issue in the case of oral prophylaxis. Table 9 summarizes the pros and cons of IM versus oral prophylactic administration of vit K. Studies showed an increased prevalence and incidence of late VKDB in the event of oral prophylaxis [37,62]. Zurynski et al. reported in 2020 a significant increase in parental refusal: in the second half of the study, the number of VKDB cases following parental refusal doubled [43]. Busfield et al. stated parental refusal already in 
2013 as the most important issue in the prophylactic prevention of VKDB [41]. Loyal et al. reported that the refusal of IM vit $\mathrm{K}$ by parents was notably higher among home births and in birthing centers. The main reasons for refusal were: concern of pain and harm from the injection and a desire to be natural and a belief in alternative methods of prophylaxis [63]. There are many factors contributing to determine an optimal vit $\mathrm{K}$ administration regimen e.g., cost, accessibility, compliance, ease of use, effectiveness, contra-indication, side-effects, parental refusal, or health care organizations. A risk with an IM injection is a potential local reaction such as an infection or muscle bleeding at the injection site. Von Kries investigated in 1992 potential complications following IM injection of vit K and found no significant complications in a study population of 420,000 neonates [36].

Table 9. Pros and cons of intramuscular and oral prophylactic administration of vitamin K.

\begin{tabular}{|c|c|}
\hline Intramuscular Vitamin K & Oral Vitamin $\mathrm{K}$ \\
\hline Advantages & Advantages \\
\hline $\begin{array}{ll}- & \text { Easy to use } \\
- & \text { Highest efficacy } \\
\text { - } & \text { Optimal compliance } \\
\text { - } & \text { Minimal cost }\end{array}$ & $\begin{array}{ll}\text { - } & \text { Easy to use } \\
\text { - } & \text { Less parental refusal }\end{array}$ \\
\hline Disadvantages & Disadvantages \\
\hline $\begin{array}{l}\text { - } \quad \text { Pain and discomfort, but can be managed effectively }[36,63,64] \\
\text { - } \\
\text { - }\end{array}$ & $\begin{array}{ll}\text { - } & \text { Lower efficacy } \\
\text { - } & \text { Compliance/adherence } \\
\text { - } & \text { Less effective in neonates with biliary atresia }\end{array}$ \\
\hline
\end{tabular}

Pain as a side-effect of an IM injection, and prevention of pain and discomfort are reasons for a higher parental refusal [34]. We are aware that our assessment of the literature and survey has focused on VKDB and does not cover the topic of pain management, but meta-analytical evidence on effective management of this needle and injection pain has been published, as Cochrane reviews highlight the efficacy in pain relief of skin-to skin contact, mother's milk and sucrose during an IM injection [64-66]. In essence, such types of interventions include swaddling/containment, skin-to-skin care, breastfeeding or sweet tasting solutions to stimulate sucking. Effective implementation of such strategies is relevant beyond the emotional and ethical aspects of pain management, as knowledge and awareness of the (long-term) psychological effects of pain in neonates increases [67]. There is an obvious need to minimalize pain during treatment procedures, including vit $\mathrm{K}$ prophylaxis.

Literature on IV administration of Vit $\mathrm{K}$ is very limited. However, anaphylactic reactions have been reported [19]. IV administration may be considered as an effective way to administer Vit $\mathrm{K}$ in newborns who already have an IV access, quite common, e.g., in preterm and (critically) ill neonates. Despite the limited data available, the majority of the Belgian NICUs prefer the IV route for vit K administration. Furthermore, the current recommendations for vit $\mathrm{K}$ prophylaxis for premature neonates vary widely.

Preterm neonates are at a higher risk of developing VKDB, due to hepatic immaturity and delayed and less-diversified gut colonization [66]. Bacterially-produced menaquinones, 2-methyl-1,4-naphthoquinones with an unsaturated polyisoprenoid chain at the 3-position, are biologically active forms of vit $\mathrm{K}$ that are present in high concentrations in the human lower bowel [46]. Menaquinones may only partially satisfy the human requirement but their contribution seems much less than previously thought [46]. While literature discusses "preterm" versus "term", recommendations focus only on birthweight, choosing $1500 \mathrm{~g}$ as the birthweight cut-off. Therefore, whenever preterm in the context of vit K prophylaxis is mentioned, a birthweight $<1500 \mathrm{~g}$ is intended. Clarke et al. suggested $0.2 \mathrm{mg} \mathrm{IM}$ once at birth for premature neonates for the prevention of early and classic VKDB [24]. The authors claim that a higher dosage could lead to an accumulation of vit $K$, but they mentioned as well that three infants from the $0.2 \mathrm{mg}$ group had undetectable serum vit 
$\mathrm{K} 1$ as early as the third postnatal week without any evidence of even a mild functional deficiency [60]. On the other hand, adverse effects of a high-dosage administration of vit $\mathrm{K}$ were not reported. A Cochrane review from 2018 concluded that dosage studies suggest that doses of vit $\mathrm{K}$ administered to preterm infants lead to supraphysiologic levels [47]. The authors of the Cochrane review conclude that in the absence of evidence that vit $K$ is harmful or ineffective and since vit $\mathrm{K}$ is an inexpensive drug, it seems prudent to follow the recommendations of expert bodies and give vit $K$ to preterm infants [47]. The voting among Belgian pediatrics illustrates the restraints for IM injection in preterm, despite the small volume of $0.1 \mathrm{~mL}$, and despite the poor knowledge about the metabolism after IV injection and possible anaphylactic reactions [19]. Further research is needed to establish an optimal dose in preterm. In the meantime, we recommend the same attitude independent of the gestational age. When IM administration is not possible, a single administration of $0.5 \mathrm{mg}$ IV is recommended. Since IV administration of lipids is part of total parenteral nutrition and since most IV lipids do contain vit $K$, repeat administrations of vit $K$ are not recommended as long as IV lipids with vit $\mathrm{K}$ are administered. When IV feeding is discontinued, IM administration of $1 \mathrm{mg}$ vit $\mathrm{K}$ is recommended.

\section{Conclusions}

It has been reported to be ethical to provide nudges in medical decision-making about vit K prophylaxis [48]. During prenatal visits, the injection should be reviewed, discussed, recommended as the default and reinforced that this is the best way to keep their upcoming newborn baby healthy [48]. Prophylactic vit K supplementation is necessary to prevent VKDB in neonates and infants. However, the route of administration and most optimal dosage are still debated. Considering evidence form literature and recommendations by scientific societies and by multiple countries, a consensus was reached by the authors of this paper resulting in a Belgian recommendation.

1. For term born infants, we recommend the administration of $1 \mathrm{mg}$ IM vit $\mathrm{K}$ once at birth to all term neonates.

2. In case of parental refusal of the IM administration, healthcare providers should inform the parents about a slightly inferior alternative, $2 \mathrm{mg}$ oral vit $\mathrm{K}$ at birth followed by the administration of 1 or $2 \mathrm{mg}$ oral vit $\mathrm{K}$, weekly for 3 months in breastfed infants, with specific attention to compliance. No further supplementation is needed after birth in formula-fed infants, neither in mixed breast nor formula feeding once formula feeding exceeds $50 \%$ of the intake.

3. In preterm neonates (also $<32$ weeks' gestation), we recommend the same approach as in term neonates. In case IM administration is not possible, $0.5 \mathrm{mg}$ IV single administration is recommended, followed by a $1 \mathrm{mg}$ IM administration when intravenous lipids are discontinued.

4. Infants with cholestasis or another disease associated with fat-malabsorption need vit $\mathrm{K}$ (and other fat-soluble vitamins) supplementation regardless of the mode of feeding in order to prevent vitamin $\mathrm{K}$ deficiency-related coagulation disorders.

Author Contributions: Conceptualization, S.F., A.S., K.A. and Y.V.; methodology, S.F., A.S., K.A., M.V.W., K.K. and Y.V.; data curation, S.F., A.S., K.A., M.V.W. and K.K.; writing-original draft preparation, S.F., A.S., M.R. (Maissa Rayyan), K.A. and Y.V.; writing-review and editing, S.F., A.S., M.R. (Maissa Rayyan), K.A., P.A., W.A., P.A., W.A., A.B., L.C., A.D.G., N.D.M., I.G., E.H., K.K., N.K.; M.R. (Marc Raes); P.P.; B.V.O.; M.V.W., V.V. and Y.V.; supervision, A.S., K.A., M.V.W. and Y.V. All authors have read and agreed to the published version of the manuscript.

Funding: This research received no external funding.

Institutional Review Board Statement: The Ethics Committee of the University Hospitals Leuven (Belgium) approved the questionnaire protocol (study MP017253).

Acknowledgments: Groups: Vlaamse Vereniging voor Kindergeneeskunde, Groupement Belge des Pédiatres de Langue Française, Bel-gische Vereniging voor Kindergeneeskunde/Société Belge de 
Pédiatrie, the Belgian Academy of Paediatrics, Kind en Gezin, Belgische Vereniging Neonatologie/Groupement Belge de Néonatologie.

Conflicts of Interest: The authors declare no conflict of interest.

\section{References}

1. Shearer, M.J. Vitamin K. Lancet 1995, 345, 229-334. [CrossRef]

2. McNinch, A. Vitamin K deficiency bleeding: Early history and recent trends in the United Kingdom. Early Hum. Dev. 2010, 86, 63-65. [CrossRef] [PubMed]

3. Puckett, R.M.; Offringa, M. Prophylactic vitamin K for vitamin K deficiency bleeding in neonates. Cochrane Database Syst. Rev. 2000, 2000, Cd002776. [CrossRef]

4. von Kries, R.; Hachmeister, A.; Göbel, U. Can 3 oral 2 mg doses of vitamin K effectively prevent late vitamin K deficiency bleeding? Eur. J. Pediatr. 1999, 158, 183-186. [CrossRef]

5. Lane, P.A.; Hathaway, W.E. Vitamin K in infancy. J. Pediatr. 1985, 106, 351-359. [CrossRef]

6. Matsuda, I.; Nishiyama, S.; Motohara, K.; Endo, F.; Ogata, T.; Futagoishi, Y. Late neonatal vitamin K deficiency associated with subclinical liver dysfunction in human milk-fed infants. J. Pediatr. 1989, 114, 602-605. [CrossRef]

7. von Kries, R.; Hanawa, Y. Neonatal vitamin K prophylaxis. Report of scientific and standardization subcommittee on perinatal haemostasis. Thromb. Haemost. 1993, 69, 293-295. [PubMed]

8. Lehman, J. Vitamin K as prophylaxis in 13,000 infants. Lancet 1944, 243, 493-494. [CrossRef]

9. Araki, S.; Shirahata, A. Vitamin K deficiency bleeding in infancy. Nutrients 2020, 12, 780. [CrossRef]

10. Zeissig, S.; Blumberg, R.S. Life at the beginning: Perturbation of the microbiota by antibiotics in early life and its role in health and disease. Nat. Immunol. 2014, 15, 307-310. [CrossRef]

11. Golding, J.; Greenwood, R.; Birmingham, K.; Mott, M. Childhood cancer, intramuscular vitamin K, and pethidine given during labour. Br. Med. J. 1992, 305, 341-346. [CrossRef]

12. Roman, E.; Fear, N.; Ansell, P. United Kingdom Childhood Cancer Study. Vitamin K and childhood cancer: A report from the United Kingdom Childhood Cancer Study. Br. J. Cancer 2003, 89, 1228-1231. [CrossRef]

13. Roman, E.; Fear, N.; Ansell, P.; Bull, D.; Draper, G.; McKinney, P.; Michaelis, J.; Passmore, S.J.; von Kries, R. Vitamin K and child-hood cancer: Analysis of individual patient data from six case-control studies. Br. J. Cancer 2002, 86, 63-69. [CrossRef]

14. Passmore, S.; Draper, G.; Brownbill, P. Case-control studies of relation between childhood cancer and neonatal vitamin K administration. BMJ 1998, 316, 178-184. [CrossRef]

15. von Kries, R.; Shearer, M.J.; Göbel, U. Vitamin K in infancy. Eur. J. Pediatr. 1988, 147, 106-112. [CrossRef]

16. O'Connor, M.E.; Addiego, J.E., Jr. Use of oral vitamin K1 to prevent hemorrhagic disease of the newborn infant. J. Pediatr. 1986, 108, 616-619. [CrossRef]

17. Busfield, A.; McNinch, A.; Tripp, J. Neonatal vitamin K prophylaxis in Great Britain and Ireland: The impact of perceived risk and product licensing on effectiveness. Arch. Dis. Child. 2007, 92, 754-758. [CrossRef] [PubMed]

18. Loughnan, P.M.; McDougall, P.N.; Balvin, H.; Doyle, L.W.; Smith, A.L. Late onset haemorrhagic disease in premature infants who received intravenous vitamin K1. J. Paediatr. Child Health 1996, 32, 268-269. [CrossRef]

19. Fiore, L.D.; Scola, M.A.; Cantillon, C.E.; Brophy, M.T. Anaphylactoid reactions to vitamin K. J. Thromb. Thrombolysis 2001, 11, 175-183. [CrossRef] [PubMed]

20. Lembo, C.; Buonocore, G.; Perrone, S. The challenge to define the optimal prophylactic regimen for vitamin K deficiency bleeding in infants. Acta Paediatr. 2021, 110, 1113-1118. [CrossRef] [PubMed]

21. van Haard, P.; Engel, R.; Postma, T. Routine clinical determiniation of carotene, vitamin E, vitamin A, 25-hydroxy vitamin D3 and trans-vitamin K 1 in human serum by straight phase HPLC. Biomed. Chromatogr. 1987, 2, 79-88. [CrossRef] [PubMed]

22. Hogenbirk, K.; Peters, M.; Bouman, P.; Sturk, A.; Büller, H.A. The effect of formula versus breast feeding and exogenous vit-amin K1 supplementation on circulating levels of vitamin K1 and vitamin K-dependent clotting factors in newborns. Eur. J. Pediatr. 1993, 152, 72-74. [CrossRef] [PubMed]

23. Costakos, D.T.; Greer, F.R.; Love, L.A.; Dahlen, L.R.; Suttie, J.W. Vitamin K prophylaxis for premature infants: $1 \mathrm{mg}$ versus $0.5 \mathrm{mg}$. Am. J. Perinatol. 2003, 20, 485-490. [CrossRef] [PubMed]

24. Clarke, P.; Mitchell, S.J.; Wynn, R.; Sundaram, S.; Speed, V.; Gardener, E.; Roeves, D.; Shearer, M.J. Vitamin K prophylaxis for preterm infants: A randomized, controlled trial of 3 regimens. Pediatrics 2006, 118, 1657-1666. [CrossRef]

25. Jørgensen, F.S.; Felding, P.; Vinther, S.; Andersen, G.E. Vitamin K to neonates: Peroral versus intramuscular administration. Acta Paediatr. 1991, 80, 304-307. [CrossRef]

26. Hathaway, W.E.; Isarangkura, P.B.; Mahasandana, C.; Jacobson, L.; Pintadit, P.; Pung-Amritt, P.; Gren, G. Comparison of oral and parenteral vitamin K prophylaxis for prevention of late hemorrhagic disease of the newborn. J. Pediatr. 1991, 119, 461-464. [CrossRef]

27. Cornelissen, E.; Kollée, L.A.A.; de Abreu, R.A.; van Baal, J.M.; Motohara, K.; Verbruggen, B.; Monnens, L.A. Effects of oral and intramuscular vitamin K prophylaxis on vitamin K 1, PIVKA-II, and clotting factors in breast fed infants. Arch. Dis. Child. 1992, 67, 1250-1254. [CrossRef]

28. Cornelissen, E.; Monnens, L. Evaluation of various forms of vitamin-K prophylaxis in breastfed infants. Ned. Tijdschr. Geneesk. 1993, 137, 2205-2208. 
29. Gupta, J.; Salonikas, C.; Naidoo, D. Neonatal plasma vitamin K1 levels following oral and intramuscular administration of vitamin K1. Acta Paediatr. 1994, 83, 133-134. [CrossRef]

30. Greer, F.R.; Marshall, S.P.; Severson, R.R.; Smith, D.A.; Shearer, M.J.; Pace, D.G.; Joubert, P.H. A new mixed micellar preparation for oral vitamin K prophylaxis: Randomised controlled comparison with an intramuscular formulation in breast fed infants. Arch. Dis. Child. 1998, 79, 300-305. [CrossRef]

31. Pereira, S.P.; Shearer, M.J.; Williams, R.; Mieli-Vergani, G. Intestinal absorption of mixed micellar phylloquinone (vitamin K1) is unreliable in infants with conjugated hyperbilirubinaemia: Implications for oral prophylaxis of vitamin K deficiency bleeding. Arch. Dis. Child Fetal Neonatal Ed. 2003, 88, F113-F118. [CrossRef] [PubMed]

32. Sann, L.; Leclercq, M.; Guillaumont, M.; Trouyez, R.; Bethenod, M.; Bourgeay-Causse, M. Serum vitamin K1 concentrations after oral administrationof vitamin K1 in low birth weight infants. J. Pediatr. 1985, 107, 608-611. [CrossRef]

33. McNinch, A.W.; Upton, C.; Samuels, M.; Shearer, M.J.; McCarthy, P.; Tripp, J.H.; Le Orme, R. Plasma concentrations after oral or intramuscular vitamin K1 in neonates. Arch. Dis. Child. 1985, 60, 814-818. [CrossRef] [PubMed]

34. Schubiger, G.; Tönz, O.; Grüter, J.; Shearer, M.J. Vitamin K1 concentration in breast-fed neonates after oral or intramuscular administration of a single dose of a new mixed-micellar preparation of phylloquinone. J. Pediatr. Gastroenterol. Nutr. 1993, 16, 435-439. [CrossRef] [PubMed]

35. Shoshkes, M.; Epplebaum, A.; Wilner, M. Oral phytonadione in neonatal hypoprothrombinemia. J. Pediatr. 1959, 55, 80-84. [CrossRef]

36. von Kries, R.; Göbel, U. Vitamin K prophylaxis and vitamin K deficiency bleeding (VKDB) in early infancy. Acta Paediatr. 1992, 81, 655-657. [CrossRef]

37. Cornelissen, E.; von Kries, R.; Loughnan, P.; Schubiger, G. Prevention of vitamin K deficiency bleeding: Efficacy of different multiple oral dose schedules of vitamin K. Eur. J. Pediatr. 1997, 156, 126-130. [CrossRef]

38. Hansen, K.N.; Minousis, M.; Ebbesen, F. Weekly oral vitamin K prophylaxis in Denmark. Acta Paediatr. 2003, 92, 802-805. [CrossRef]

39. McNinch, A.; Busfield, A.; Tripp, J. Vitamin K deficiency bleeding in Great Britain and Ireland: British Paediatric Surveillance Unit Surveys, 1993-1994 and 2001-2002. Arch. Dis. Child. 2007, 92, 759-766. [CrossRef]

40. Darlow, B.A.; Phillips, A.A.; Dickson, N.P. New Zealand surveillance of neonatal vitamin K deficiency bleeding (VKDB): 1998-2008. J. Paediatr. Child Health 2011, 47, 460-464. [CrossRef]

41. Busfield, A.; Samuel, R.; McNinch, A.; Tripp, J.H. Vitamin K Deficiency Bleeding after NICE Guidance and Withdrawal of Konakion Neonatal: British Paediatric Surveillance Unit study, 2006-2008. Arch. Dis. Child. 2013, 98, 41-47. [CrossRef] [PubMed]

42. Löwensteyn, Y.N.; Jansen, N.J.G.; van Heerde, M.; Klein, R.H.; Kneyber, M.C.J.; Kuiper, J.W.; Riedijk, M.A.; Verlaat, C.W.M.; Visser, I.H.E.; van Waardenburg, D.A.; et al. Increasing the dose of oral vitamin K prophylaxis and its effect on bleeding risk. Eur. J. Pediatr. 2019, 178, 1033-1042. [CrossRef]

43. Zurynski, Y.; Grover, C.J.; Jalaludin, B.; Elliott, E.J. Vitamin K Deficiency Bleeding in Australian Infants 1993-2017: An Australian Paediatric Surveillance Unit study. Arch. Dis. Child. 2020, 105, 433-438. [CrossRef]

44. Witt, M.; Kvist, N.; Jørgensen, M.H.; Hulscher, J.B.F.; Verkade, H.J. Prophylactic dosing of Vitamin K to prevent bleeding. Pediatrics 2016, 137, 20154222. [CrossRef]

45. van Hasselt, P.M.; De Koning, T.J.; Kvist, N.; de Vries, E.; Lundin, C.R.; Berger, R. Prevention of vitamin K deficiency bleeding in breastfed infants: Lessons from the dutch and danish biliary atresia registries. Pediatrics 2008, 121, 857-863. [CrossRef]

46. Suttie, J.W. The importance of menaquinones in human nutrition. Ann. Rev. Nutr. 1995, 15, 399-417. [CrossRef] [PubMed]

47. Ardell, S.; Offringa, M.; Ovelman, C.; Soll, R. Prophylactic vitamin K for the prevention of vitamin K deficiency bleeding in preterm neonates. Cochrane Database Syst. Rev. 2018, 2, CD008342. [CrossRef]

48. Moses, B.D.; Borecky, A.D.; Dubov, A. It is OK to nudge for vitamin K. Acta Paediatr. 2019, 108, 1938-1941. [CrossRef] [PubMed]

49. Keiren, K.; van Winckel, M.; Allegaert, K. A snapshot on current practices and recent trends on vitamin K prophylaxis in term neonates in Flanders. B. J. Pediatr. 2021; unpublished.

50. American Academy of Pediatrics Committee on Fetus and Newborn. Controversies Concerning Vitamin K and the Newborn. Pediatrics 2003, 112, 191-192. [CrossRef]

51. McNinch, A.; Tripp, J. Haemorrhagic disease of the newborn in the British Isles: Two year prospecitve study. BMJ 1991, 303, 1105-1109. [CrossRef]

52. Schubiger, G.; Berger, T.; Weber, R.; Banziger, O.; Laubscher, B. Prevention of vitamin K deficiency bleeding with oral mixed micellar phylloquinone: Results of a 6-year surveillance in Switzerland. Eur. J. Pediatr. 2003, 162, 885-888. [CrossRef]

53. Cottam, S.T.; Connett, G.J. Routine use of daily oral vitamin K to treat infants with cystic fibrosis. Paediatr. Respir. Rev. 2015, 16, 22-24. [CrossRef] [PubMed]

54. American Academy of Pediatrics Committee on Nutrition. Vitamin K Compounds and the Water-Soluble Analogues: Use in Therapy and Prophylaxis in Pediatrics. Pediatrics 1961, 28, 501-507.

55. American Academy of Pediatrics Vitamin K Ad Hoc Task Force. Controversies Concerning Vitamin K and the Newborn. Pediatrics 1993, 91, 1001-1003.

56. Ng, E.; Loewy, A.D. Fetus and Newborn Committee. Guidelines for vitamin K prophylaxis in newborns. J. Paediatr. Child. Health 2018, 23, 394-402. [CrossRef] 
57. Loughnan, P.; McDougall, P. Does intramuscular vitamin K1 act as an unintended depot preparation? J. Paediatr. Child. Health 1996, 32, 251-254. [CrossRef]

58. Mihatsch, W.A.; Braegger, C.; Bronsky, J.; Campoy, C.; Domellöf, M.; Fewtrell, M. Prevention of Vitamin K deficiency bleeding in newborn infants: A position paper by the ESPGHAN committee on nutrition. J. Pediatr. Gastroenterol. Nutr. 2016, 63, 123-129. [CrossRef]

59. Wariyar, U.; Hilton, S.; Pagan, J.; Tin, W.; Hey, E. Six years' experience of prophylactic oral vitamin K. Arch. Dis. Child. Fetal Neonatal Ed. 2000, 82, F64-F68. [CrossRef]

60. Shearer, M. Vitamin K deficiency bleeding (VKDB) in early infancy. Blood Rev. 2009, 23, 49-59. [CrossRef]

61. Ciantelli, M.; Bartalena, L.; Bernardini, M.; Biver, P.; Chesi, F.; Boldrini, A.; Sigali, E. Late vitamin K deficiency bleeding after intramuscular prophylaxis at birth: A case report. J. Perinatol. 2009, 29, 168-169. [CrossRef] [PubMed]

62. Croucher, C.; Azzopardi, D. Compliance with recommendations for giving vitamin K to newborn infants. BMJ 1994, 308, 894-895. [CrossRef] [PubMed]

63. Loyal, J.; Shapiro, E.D. Refusal of intramuscular vitamin K by parents of newborns: A review. Hosp. Pediat. 2020, 10, 286-294. [CrossRef] [PubMed]

64. Johnston, C.; Campbell-Yeo, M.; Fernandes, A.; Inglis, D.; Streiner, D.; Zee, R. Skin-to-skin care for procedural pain in neonates. Cochrane Database Syst. Rev. 2014, 1, CD008435. [CrossRef]

65. Shah, P.S.; Herbozo, C.; Aliwalas, L.L.; Shah, V.S. Breastfeeding or breast milk for procedural pain in neonates. Cochrane Database Syst. Rev. 2012, 12, CD004950. [CrossRef]

66. Stevens, B.; Yamada, J.; Ohlsson, A.; Haliburton, S.; Shorkey, A. Sucrose for analgesia in newborn infants undergoing painful procedures. Cochrane Database Syst. Rev. 2016, 7, CD001069. [CrossRef]

67. Taddio, A.; Katz, J.; Ilersich, A.; Koren, G. Effect of neonatal circumcision on pain response during subsequent routine vaccination. Lancet 1997, 349, 599-603. [CrossRef] 